УдК 616.31- 089.444

DOI 10.11603/2411-1597.2019.4.10828

\title{
РОЛЬ МЕДИЧНОЇ СЕСТРИ В УКРАЇНI ТА У СВІТІ
}

\author{
Н. М. Абашник \\ Комунальне некомерційне підприємство Харківської обласної ради \\ "Обласна клінічна лікарня"
}

У статті проведено порівняльний аналіз ролі медичної сестри в Україні та у світі.

THE ROLE OF A NURSE IN UKRAINE AND IN THE WORLD

\author{
N. M. Abashnyk \\ Communal Non-profit Enterprise of the Kharkiv Regional Council "Regional Clinical Hospital"
}

The article provides a comparative analysis of the role of a nurse in Ukraine and in the world.

Вступ. Європейська конференція із сестринської справи (Відень, 1988) наголосила, що без сестер медичних немає майбутнього [1]. Такий підхід до значимості сестринської справи як складової частини системи охорони здоров'я та особи сестри медичної залишається актуальним і на XXI століття. Аналіз європейських матеріалів щодо ролі медичної сестри в суспільстві засвідчує, що вагомість цієї професії зростає не тільки в Україні, а й в цілому світі. Актуальність цієї теми полягає в тому, що відбувається активне формування законодавчої бази в галузі медсестринства та необхідність прискорення адаптації вітчизняної нормативно-правової бази до європейських норм, зокрема це стосується кадрового забезпечення та наближення вітчизняного рівня заробітної плати медичних сестер України до світового.

Наказом МОЗ України від 10.04.2019 р. № 805 внесено зміни до Довідника кваліфікаційних характеристик професій працівників, де терміни «медична сестра» змінено на «сестра медична» «брат медичний». Тож надалі в тексті будемо вживати саме такі терміни [8].

Основна частина. Молодші спеціалістиз медичною освітою у будь-якій країні світу, в тому числі й в Україні, $\epsilon$ найчисельнішим загоном медичної спільноти. Саме від них значною мірою залежить якість надання медичної допомоги пацієнтам. Це ті фахівці, які супроводжують людину протягом усього її життя.

Без перебільшення можна сказати, що професія сестри медичної є унікальною. Кожна людина, якій (c) Н. М. Абашник, 2019 потрібна допомога медичної сестри, чекає від неї не лише професіоналізму, але і великого співчуття, чуйного ставлення, тієї душевної теплоти, яка так необхідна людині у боротьбі з недугою.

До компетенцій сестри медичної повинні входити вміння забезпечувати індивідуальний підхід до хворого, навички співпраці з родинами пацієнтів, якості менеджера та психолога у галузі ділових і людських відносин.

Сучасний пацієнт очікує якісних медичних послуг, що вимагає від сестер медичних розширених професійних знань та навичок, вміння встановити сестринський діагноз, користуватись сучасною медичною апаратурою, мати доступ до інформації щодо останніх досягнень у медицині. У ряді розвинених країн саме медичні сестри є першим, останнім та найбільш постійним ланцюгом контакту пацієнта з системою медичної допомоги та охорони здоров'я.

Реформа системи охорони здоров'я значною мірою стосуватиметься і реформування інституту медсестринства [7].

На сьогодні багато уваги приділяють реформуванню ступеневої медсестринської освіти, яка передбачає корекцію підготовки сестри медичної до рівня європейських стандартів.

Однак, варто відзначити, що удосконалення медсестринської освіти значно випереджає зміни в практичному медсестринстві.

Виходячи із даного аналізу, потрібно в період реформування сестринської справи у практичній 
системі охорони здоров'я вже закладати європейські стандарти компетентностей середнього медичного персоналу. Найпершим і найголовнішим моментом реформування в медсестринстві $\epsilon$ питання стратегічного планування розвитку інституту медсестринства в Україні [7].

У період фундаментальних реформ у галузі охорони здоров'я середній медичний персонал все частіше розцінюють як ключовий ресурс реформування медичної галузі. Будучи найчисельнішою категорією працівників медичної допомоги і працюючи в найрізноманітніших умовах, медичні сестри, акушерки, фельдшери роблять значний внесок у виконання всіх поставлених завдань щодо покращення здоров'я населення шляхом виконання системних завдань діагностики, лікування та реабілітації.

Сучасне трактування ВоОз сестринської справи містить не лише визначення ії місця і завдань у системі охорони здоров'я, а й чітко окреслює коло функціональних обов'язків: «Сестринська справа це складова частина системи охорони здоров'я, яка спрямована на вирішення проблем індивідуального та громадського здоров'я населення в мінливих умовах навколишнього середовища. Сестринська справа включає діяльність із зміцнення здоров'я, профілактики захворювань, надання психосоціальної допомоги особам, які мають фізичні та (або) психічні захворювання, а також непрацездатним всіх вікових груп» [6].

В європейських країнах сестра медична є повністю самостійна, вона має право прийняти ті рішення, які стосуються сестринського персоналу, їм доступна вища освіта за своєю спеціальністю, тисячі наших колег займаються не тільки педагогічною, але й науковою діяльністю, результати їх праці лягають в основу більш удосконалених принципів організації медичної допомоги. Здійснюються певні кроки щодо престижу професії та освіти сестри медичної як найбільш потрібної та масової в практичній охороні здоров'я. Запровадження ступеневої неперервної вищої медсестринської освіти підносить ії на один рівень з лікарською. Але в цьому питанні $є$ ще багато проблем.

у багатьох європейських країнах медичні сестри складають основу первинної ланки охорони здоров'я. Так, у шведській системі охорони здоров'я медичні сестри відіграють все більшу роль, надаючи висококваліфіковану допомогу пацієнтам із хронічними і тяжкими станами (цукровий діабет, бронхіальна астма, серцева недостатність, психічні захворюван- ня); їм також надано обмежене право призначення лікарських засобів [2]. У шведських медичних центрах пацієнта спочатку оглядає медсестра, яка потім може скерувати пацієнта до лікаря загальної практики або в лікарню.

У Фінляндії 80 \% пацієнтів попередньо консультують медсестри, а потім, у разі необхідності, скеровують до лікарів, і тільки 20 \% пацієнтів поступають безпосередньо до лікарів. У Скандинавських країнах у містах і селах у центрах здоров'я також провідну роль відіграють сестри медичні. У Нідерландах рішення про надання допомоги пацієнтам лікарями в позаробочий час приймає медсестра на основі встановлених критеріїв. У своїй діяльності медичні сестри спираються на клінічні протоколи і мають право в межах цих протоколів змінювати режим медикаментозної терапії [3].

В Англії медичні сестри, які спеціалізуються на допомозі людям із певними захворюваннями (цукровий діабет або бронхіальна астма), у повсякденній діяльності замінюють лікарів загальної практики - ведуть амбулаторний прийом для спостереження і навчання пацієнтів або займаються виїзною та освітньою діяльністю, спрямованою на підвищення кваліфікації інших медичних і соціальних працівників [4].

У США та Німеччині впроваджено структуровані програми ведення захворювань для деяких станів (case management), такий підхід зумовлений тим, що лікарі в цих країнах найчастіше мають індивідуальну практику, а амбулаторний і лікарняний сектори відокремлені один від одного. Медичні сестри в багатьох випадках проводять первинне обстеження і скеровують пацієнта до відповідних закладів охорони здоров'я [5]. У розвинених європейських країнах лікарі загальної практики, як правило, не відвідують пацієнтів вдому, за винятком рідкісних випадків, тому це робота підготовлених медсестер.

Заробітна плата в європейських країнах сестри медичної становить приблизно 34 тис. доларів на рік, а в Україні - 2 тис. доларів на рік [6].

Беручи до уваги такий високий рівень заробітної плати сестер медичних у світі, українська медична сестра має високу мотивацію змінити місце роботи. Однак, варто відзначити, що для своєї реалізації як сестри медичної за кордоном, нашим медсестрам необхідно буде пройти процес сертифікації знань. У функції медсестри в Європі входить більше повноважень, вищий рівень освіти, дещо інша структура підготовки і діяльність прирівнюються практично до 
рівня лікаря, звідки і роль медичної сестри набагато вища, ніж в Україні.

На жаль, в Україні, роль сестри медичної ще й досі зведена до виконання обов'язків помічника лікаря - і пацієнти, і лікарі сприймають ії здебільшого як сестру милосердя, що, разом із мізерною заробітною платнею зумовлює низький соціальний статус наших медичних сестер.

Норми навантажень на сестер медичних і нормативи оснащення їх робочих місць не відповідають сучасним вимогам. Сьогодні медсестра в Україні опікується 20-30 пацієнтами, її колега в Європі - 5. Тож необхідно переглянути нормативи штатів медсестринських кадрів (у бік збільшення показника лікар - сестра медична 1:5) та кількість пацієнтів (у бік зменшення), які обслуговує одна медична сестра, особливо в тяжких відділеннях (відділення реанімації, хірургії, кардіології).

Необхідно звернути увагу на засилля нетипових для медсестер функцій, які в розвинених країнах виконують санітари. Сьогодні на наших сестер медичних покладено функції, пов'язані з транспортуванням, підніманням, переміщенням пацієнтів, біксів з операційним інструментарієм тощо. Важливим і, на жаль, невирішеним $є$ питання безпеки сестри медичної на робочому місці. Це і відсутність належного протиепідемічного захисту, і постійна робота з дезінфекційними та лікарськими засобами, і нестача спеціального одягу, інколи бувають напади на сестер медичних із боку пацієнтів.

Надмірна завантаженість медсестер призводить до раннього професійного вигорання, відсутність засобів індивідуального захисту є причиною масової алергізації, а незахищеність перед агресією деяких пацієнтів виражено знижує мотивацію освоєння такого фаху, як сестра медична.

У процесі реформування галузі виникли нові умови праці, зокрема перехід на електронний документообіг, що зобов'язує медичних працівників освоювати комп'ютерну техніку, роботу з програмними продуктами, вивчати нові класифікаційні норми тощо. Тривала робота за монітором вимагає іншого нормативного регламентування робочого часу, перерозподілу обов'язків тощо.

Вже сьогодні можна сказати, що ситуація з кадровим забезпеченням медичними сестрами катастрофічна (60 \% від потреби). Держава недостатньо моти- вує сестер медичних до професійної діяльності, що спричиняє масову трудову міграцію.

Висновки. Із вищевикладеного можемо зробити висновок, що в Україні престижність професії сестри медичної є значно меншою, ніж у розвинених країнах світу. І одним із головних факторів, що спричиняє уже масову трудову еміграцію, є мізерна заробітна плата. Щорічно Україну залишають, за неофіційними даними, близько 7 тис. медичних працівників.

Саме держава повинна стати гарантом у забезпеченні зростання ролі сестри медичної в житті кожного громадянина.

Низька заробітна плата, відсутність належних умов праці, завантаженість рутинною роботою, соціальна і професійна незахищеність, необхідність працювати за себе й за колег, яких катастрофічно не вистачає, перебування у «тіні лікаря» - це основні фактори зниження ролі медичної сестри в Україні та проблеми всього вітчизняного медсестринства, які повинні вирішуватися на державному рівні:

1) врегулювати правову і матеріальну підтримку молодших спеціалістів з медичною освітою;

2) створити відповідні умови праці й систему адекватної її оплати;

3) визначити статус освітньо-кваліфікаційних рівнів бакалавра та магістра;

4) чітко визначити функціональні обов'язки медичних сестер-молодших спеціалістів, медичних сестербакалаврів та медичних сестер-магістрів;

5) у тарифікаційному переліку необхідно визначити наявність рівня освіти, порядок обіймання посад спеціалістами (медсестра-бакалавр, медсестра-магістр);

6) запровадити двоступеневу опіку над пацієнтами, яку 6 проводили медичні сестри 1 рівня підготовки та сестри-бакалаври (обов'язки між ними необхідно розподілити);

7) переглянути норми навантажень на медичних сестер і нормативи оснащення їх робочих місць, які 6 відповідали сучасним вимогам;

8) підвищити заробітну плату та запровадити диференціацію заробітної плати для медичних сестермолодших спеціалістів, медичних сестер-бакалаврів і медичних сестер-магістрів.

2020 р. проголошено роком медсестринства. Будемо сподіватись, що держава зробить максимум для повернення престижу професії медсестри, що зупинить процес еміграції кваліфікованих спеціалістів. 


\section{СПИСОК ЛІТЕРАТУРИ}

1. Резолюція Асамблеї ВООЗ 42.2742 сесії ВВОЗ (1989) [Електронний ресурс]. - Режим доступу : http://www.who. dk/document/e7 1523R.pdf.

2. Buchan J. Skill-mix and policy change in the Health Workforce / J. Buchan, L. Calman : Nurses in advanced roles. Paris: OECD, $2005.63 \mathrm{p}$.

3. Stromberg A. Nurse_led heart failure clinics in Sweden / A. Stromberg, J. Martensson, B. Fridlund // Eur. J. Heart Fail. 2001. - Vol. 3. - P. 139-144.

4. Karlberg I. Managing Chronic Conditions: Experience in Eight Countries / I. Karlberg. - Copenhagen: European Observatory on Health Systems and Policies, 2008. - 181 p.
5. Effizienzeines disease management programmesbei asthma / W. Petro, J. Schulenburg, W. Greiner [et al.] // Pneumologie. - 2005. - Vol. 59. - P. 101-107.

6. Авраменко Т. П. Кадрова політика у реформуванні сфери охорони здоров'я : аналітична доповідь / Т. П. Авраменко. - К. : НІСД, 2012. - 35 с.

7. Банчук М. В. Стратегія розвитку та реформування медсестринства в Україні / М. В. Банчук, О. П. Волосовець, Т. І. Чернишенко // Магістр медсестринства. - 2008. № 1. - С. 18-21.

8. Про зміни до Довідника кваліфікаційних характеристик професій працівників : наказ МОЗ України від 10.04.2019 p. № 805.

Отримано 08.11.19 